\title{
Analisis dan Perancangan Software Pengukuran Metrik Skala dan Kompleksitas Arsitektur Bisnis
}

\author{
M. Rizky Noer Alif ${ }^{1 *}$, Nisa Kholifatul Ummah ${ }^{2}$, Yessy Fatmasari ${ }^{3}$, Muhammad Ainul Yaqin ${ }^{4}$ \\ Jurusan Teknik Informatika, Universitas Islam Negeri Maulana Malik Ibrahim, Indonesia \\ 118650083@ student.uin-malang.ac.id; ${ }^{2} 18650065 @$ student.uin-malang.ac.id; ${ }^{3} 18650085 @$ student.uin-malang.ac.id; \\ 4yaqinov@ti.uin-malang.ac.id \\ * corresponding author
}

INFO ARTIKEL

Sejarah Artikel

Diterima: 3 Oktober 2019

Direvisi: 15 Februari 2020

Diterbitkan: 30 April 2020

Kata Kunci

Metrik Skala

Kompleksitas

Arsitektur Bisnis

Organisasi

\section{ABSTRAK}

Dalam menjalankan sebuah organisasi diperlukan perencanaan yang baik dari berbagai aspek termasuk dalam arsitektur bisnisnya. Penelitian kali ini menggunakan studi kasus dengan Organisasi Siswa Intra Sekolah (OSIS) sebagai objek penelitian. Masing-masing job description komponen organisasi direprentasikan dengan model proses dari Standar Operasional Prosedur (SOP) dan stakeholdernya dimodelkan dalam graph sehingga diperoleh node, edge model proses dan edge graph sebagai metrik skala kompleksitas arsitektur bisnis. Dari hasil perhitungan dan analisis regresi linier diperoleh skala kompleksitas berpengaruh positif terhadap organisasi yang berarti organisasi tersebut tumbuh.

\section{PENDAHULUAN}

Pada era Arsitektur enterprise perlu diterapkan dalam membangun sebuah organisasi. Dengan pembangunan dan pengembangan yang tepat, sebuah organisasi dapat memanfaatkan arsitektur bisnis untuk meningkatkan fungsi kerja seluruh komponen organisasi untuk mendukung pengembangan organisasi dalam jangka panjang serta sesuai dengan kebutuhan dan tujuan organisasi. Aspek terpenting dalam membangun sebuah organisasi adalah dari segi bisnis. Sebab bisnis merupakan salah satu pokok fondasi penting sebuah organisasi di mana sektor ini berpengaruh pada sektor lainnya yaitu data dan teknologi. Belum adanya sistem informasi terintegrasi serta masih banyak proses manual tersebut menyebabkan tidak lengkapnya data dan informasi yang dibutuhkan stakeholder untuk melaksanakan proses bisnis atau pengambilan keputusan [1][2].

Sektor bisnis yang memiliki peran sedemikian rupa penting perlu di bangun dengan tingkat implementasi dan tingkat keuntungan yang bagus. Sistem yang memiliki tingkat kompleksitas tinggi cenderung memiliki beberapa masalah. Sedangkan sistem yang memiliki tingkat kompleksitas rendah lebih tidak menguntungkan apabila di terapkan. Agar sistem bisnis yang dibangun dapat diketahui seberapa baik untuk diterapkan perlu dilakukan uji terhadap kompleksitas sistem bisnis tersebut. Dalam arsitektur enterprise sistem ini dikenal dengan arsitektur bisnis [3]. Oleh karena itu, dalam penelitian kali ini dilakukan perancangan Software untuk mengukur sebuah kompleksitas dari arsitektur bisnis dengan melihat metrik skalanya [4]. Yaqin dkk [2] telah melakukan penelitian tentang metrik pertumbuhan organisasi untuk menjelaskan tentang pengaruh dari struktur organisasi terhadap tingkat ke efektivitas organisasi berdasarkan kompleksitas struktur organisasinya. Paper ini menghitung kompleksitas struktur organisasinya berdasarkan Skala kompleksitas (Scale), banyaknya node (n), banyaknya edge (e), average depth dan jumlah daun (weight) yang kemudian 
setelah menghitung kompleksitasnya dapat diketahui pertumbuhan organisasi tersebut dengan metode regresi linier.

\section{METODE}

Pada perancangan Software pengukuran metrik skala dan kompleksitas arsitektur bisnis ini kami menggunakan metode yang banyak digunakan pada umumnya, yaitu Metode Waterfall. Alasan kami menggunakan metode ini dikarenakan metode ini menggunakan tahapan secara urut satu persatu.

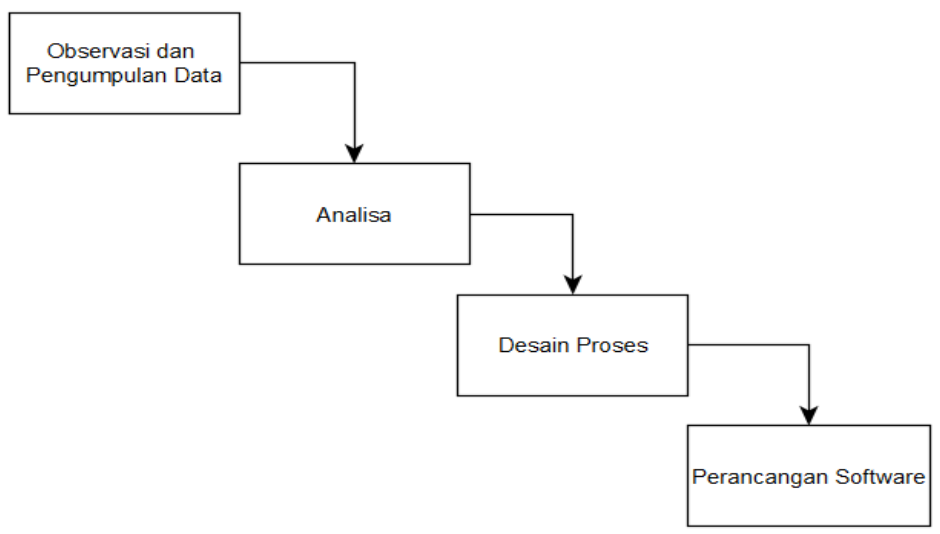

Gambar 1. Metode Waterfall

\section{Observasi dan Pengumpulan Data}

Pada tahap observasi dan pengumpulan data, kami melakukan observasi dan pengumpulan data dengan cara studi literatur seperti artikel,jurnal ilmiah dan penelitian yang bersangkutan dengan judul yang telah kami angkat [5].

\section{Analisa}

Dalam tahapan analisa ini kami melakukan analisa tentang data yang telah kita dapatkan. Metode analisa yang kami gunakan adalah metode secara semiotik, dimana analisa ini digunakan untuk menganalisa bagian seperti node, edge graph, edge konektor MP [6].

\section{Desain Proses}

Pada tahapan desain proses ini kami melakukan proses perumusan dari data yang telah kami dapatkan, proses perumusan tersebut terbagi menjadi beberapa langkah, yakni :

\section{Identifikasi metrik skala dengan Goal Question Metric (GQM).}

Identifikasi metrik skala dengan menggunakan Goal Question Metric (GQM) ini memperoleh hasil bahwa metrik yang akan digunakan adalah node, edge model proses dan edge graph [7][8].

Tabel 1. Hasil Identifikasi Metrik Menggunakan Goal Question Metric (GQM)

\begin{tabular}{|lll|}
\hline \multirow{3}{*}{ Goal } & Tujuan & Mengajukan \\
\cline { 2 - 3 } & Isu & Formula yang komprehensif dan sensitif terhadap perubahan kecil \\
\cline { 2 - 3 } & Objek & Formula kompleksitas Struktur organisasi \\
\cline { 2 - 3 } & $\begin{array}{l}\text { Sudut } \\
\text { Pandang }\end{array}$ & Peneliti \\
\hline
\end{tabular}




\begin{tabular}{|ll|}
\hline $\begin{array}{l}\text { Question } \\
\text { Metriks }\end{array}$ & $\begin{array}{l}\text { Apa yang membentuk sebuah organisasi? } \\
\text { Struktur organisasi, Job Descripstion, Standar Operasional Prosedur } \\
\text { (SOP) }\end{array}$ \\
\hline $\begin{array}{l}\text { Question } \\
\text { Metriks }\end{array}$ & Apa saja metrik skala yang pernah diajukan? \\
\hline Question & nodge, average depth, dan weight \\
Metriks & Apa saja metrik skala yang akan diajukan? \\
& Node dan edge pada model proses Standar Operasional Prosedur (SOP), \\
dan edge pada graph struktur organisasi
\end{tabular}

\section{Representasi Struktur Organisasi dan Graph Stakeholder}

Struktur organisasi yang digunakan dapat dilihat pada Gambar 2 berikut:

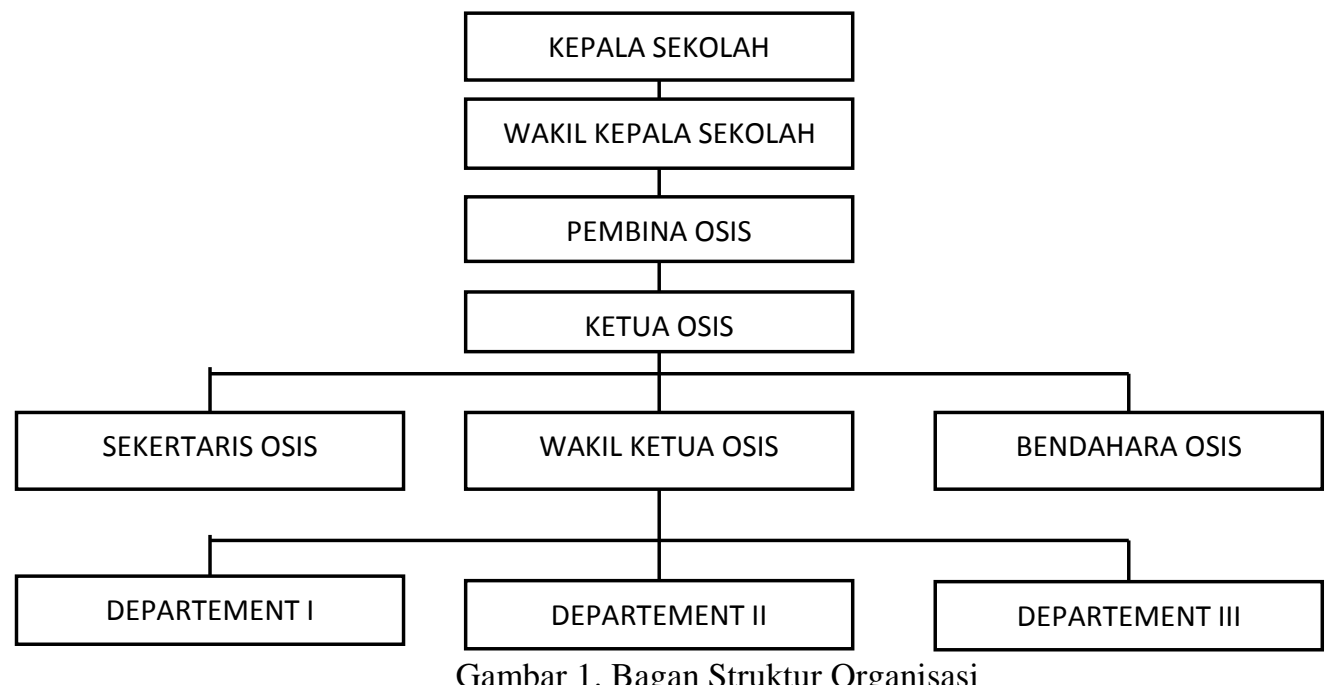

Masing-masing komponen organisasi kemudian memiliki stakeholder atau hubungan antar komponen yang kemudian direpresentasikan dalam graph sehingga masing-masing komponen akan memiliki hubungan seperti Gambar 2.

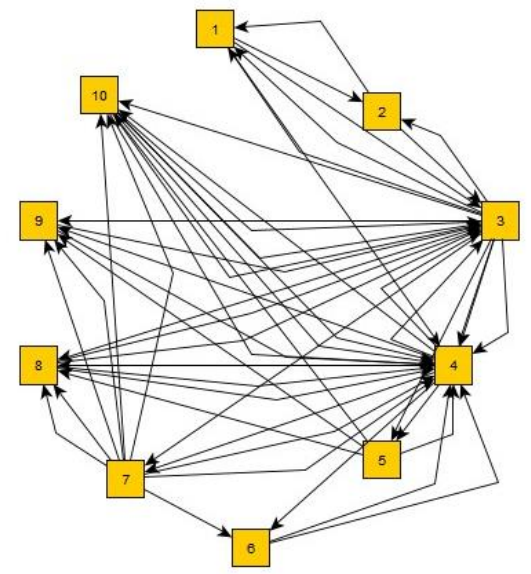

Gambar 2. Graph Hubungan antar Komponen Struktur Organisasi 


$$
\begin{aligned}
& \text { KETERANGAN: } \\
& 1=\text { Kepala Sekolah } \\
& 2=\text { Wakil Kepala Sekolah } \\
& 3=\text { Pembina } \\
& 4=\text { Ketua } \\
& 5=\text { Wakil Ketua }
\end{aligned}
$$

$$
\begin{aligned}
& 6=\text { Sekretaris } \\
& 7=\text { Bendahara } \\
& 8=\text { Departemen } 1 \\
& 9=\text { Departemen } 2 \\
& 10=\text { Departemen } 3
\end{aligned}
$$

Standar Operasional Prosedur (SOP) dari komponen organisasi yang kemudian masing-masing direpresentasikan dengan sebuah model proses dengan notasi pemodelan Business Process Modelling Notation (BPMN) seperti Gambar 4 dan Gambar 5 dimana terdapat node dan edge yang kemudian digunakan sebagai metrik skala dalam pengukuran kompleksitas.

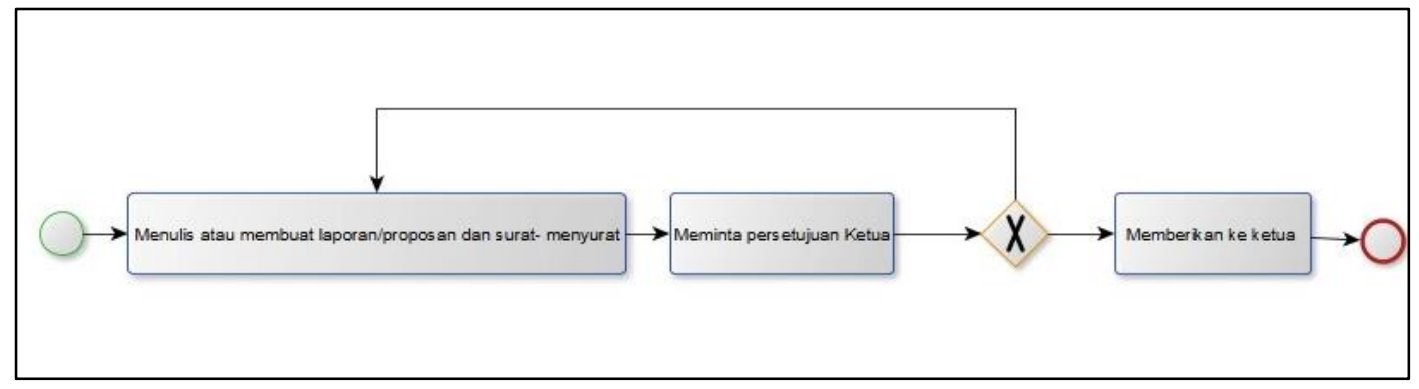

Gambar 4. Model Proses dari Standar Operasional Prosedur(SOP) 1 Sekretaris

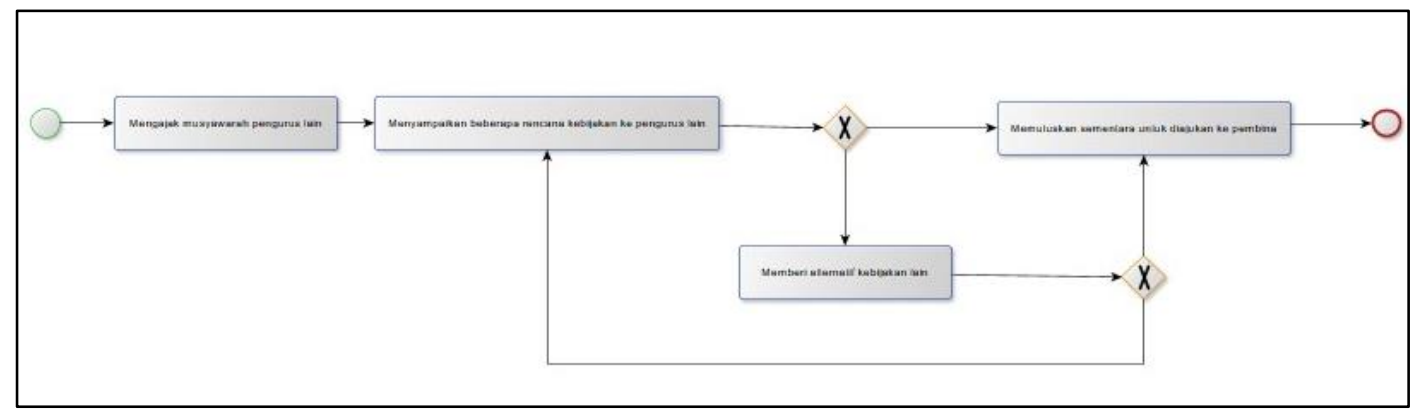

Gambar 5. Model Proses dari Standar Operasional Prosedur(SOP) 1 Ketua

Kemudian dari model proses yang telah dibuat disimpan dengan ekstensi xml dan dijadikan inputan dalam proses perhitungan selanjutnya.

\section{Formulasi Metrik menggunakan metode AHP}

Model proses dari masing-masing Standar Operasional Prosedur(SOP) dalam ekstensi $x m l$ kemudian di import ke Ms. Excel dan diperoleh data jumlah node dan edge seperti pada Tabel 2.

Tabel 2. Hasil Konversi Data dari File XML

\begin{tabular}{|lllcrl|}
\hline \multirow{2}{*}{ No } & \multirow{2}{*}{ Komponen } & \multicolumn{1}{c}{ Job description } & SOP & \multirow{2}{*}{ E } \\
\cline { 4 - 6 } $\mathbf{1}$ & Kepala Sekolah & $\begin{array}{l}\text { Bertanggung jawab atas seluruh pengelolaan,pembinaan, } \\
\text { dan pengembangan OSIS }\end{array}$ & 7 & 6 \\
\hline $\mathbf{2}$ & $\begin{array}{l}\text { Wakil Kepala } \\
\text { Sekolah }\end{array}$ & $\begin{array}{l}\text { Membantu kepala sekolah dengan memberikan nasihat dan } \\
\text { mengadakn evaluasi pelaksanaan tugas OSIS }\end{array}$ & 8 & 4 \\
\hline $\mathbf{3}$ & Pembina & $\begin{array}{l}\text { Mengesahkan dan melantik pengurus OSIS dengan Surat } \\
\text { Keputusan Kepala Sekolah }\end{array}$ & 8 & 7 & 21 \\
\hline
\end{tabular}




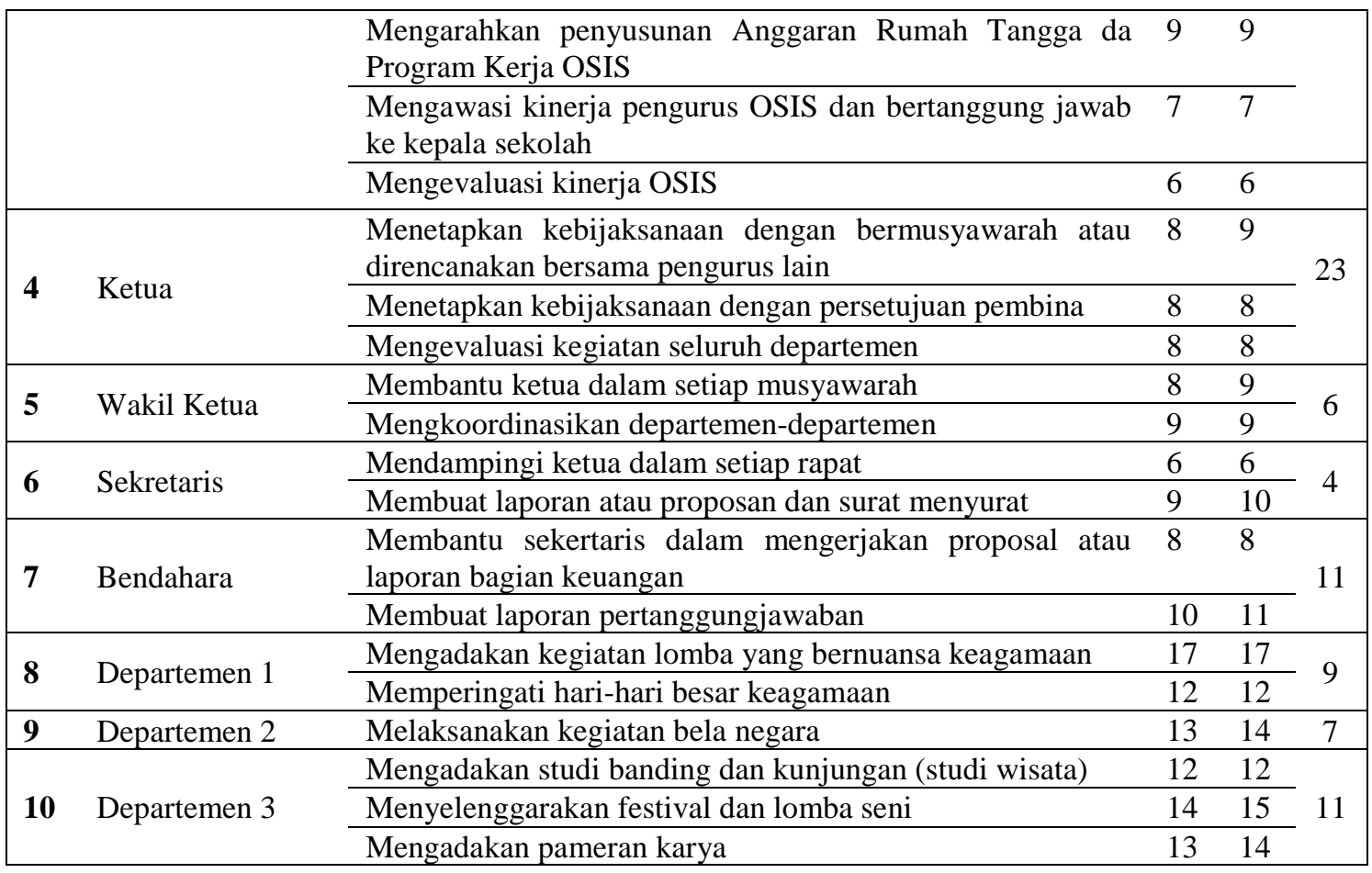

Dengan menggunakan metode Analytical Hierarchy Process (AHP) diperoleh bobot dari masing-masing metrik seperti pada Tabel 3.

Tabel 2. Bobot Masing-Masing Metrik Skala

\begin{tabular}{|lll|}
\hline NO & METRIK & BOBOT \\
\hline $\mathbf{1}$ & (A) Node & 0,233 \\
\hline $\mathbf{2}$ & (B) Edge Konektor MP & 0,429 \\
\hline $\mathbf{3}$ & (C) Edge Graph & 0,338 \\
\hline
\end{tabular}

\section{Formulasi Perhitungan Skala Kompleksitas Struktur Organisasi}

Prosedur perhitungan setelah file $x m l$ dikonversi datanya di Ms. Excel kemudian dihitung masing-masing node dan edgenya. Dengan menggunakan rumus perhitungan (1) kemudian dihitung kompleksitas masing-masing komponen organisasi dari masingmasing komponen struktur organisasi [9].

Berikut rumus yang digunakan:

$$
\text { Scale }=\frac{\sum_{i=1}^{n}\left(A \times N_{i}+B \times e_{i}\right)}{n}+C \times E
$$

dengan:

$$
\begin{array}{ll}
\text { Scale } & : \text { Skala kompleksitas } \\
N_{i} & \text { : Banyaknya node pada model proses ke } i \\
e_{i} & \text { : Banyaknya edge konektor pada model proses ke } i \\
E & \text { : Banyak edge graph komponen struktur organisasi } \\
n & : \text { Banyaknya job description }
\end{array}
$$

Rata-rata skala kompleksitas dari masing-masing Standar Operasional Prosedur (SOP) kemudian dijumlahkan dengan kompleksitas dari edge graph dari komponen struktur organisasi yang menghasilkan hasil akhir berupa kompleksitas struktur organisasi 
tersebut. Perhitungan dilanjutkan dengan menggunakan metode regresi linier untuke menentukan pengaruh skala kompleksitas terhadap struktur organisasi [10][11].

\section{Perancangan Software}

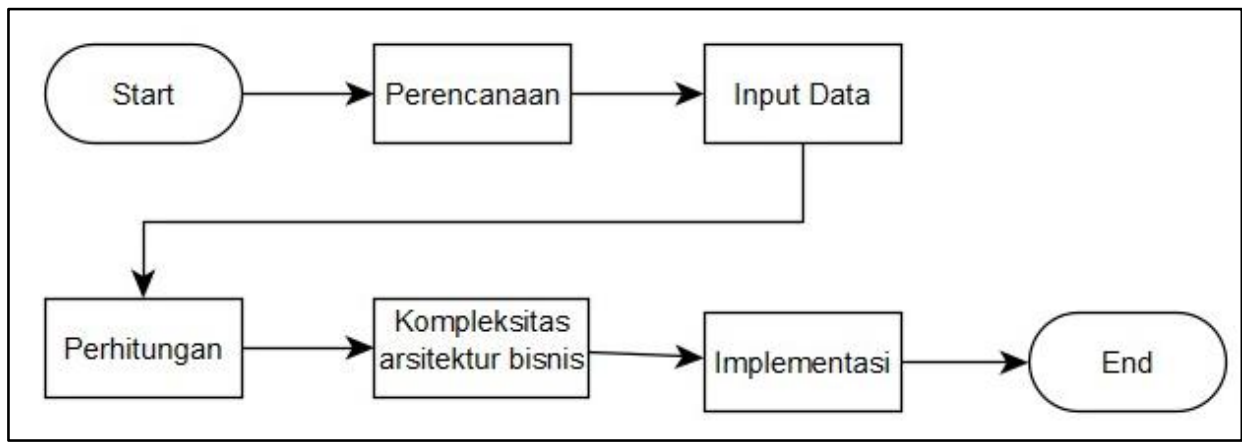

Gambar 6. Alur rancangan sistem

Pada tahapan perancangan Software perhitungan metrik skala dan kompleksitas arsitektur bisnis ini, kami menggunakan model proses dan Standar Operasional Prosedur sebagai inputan dan hasil nilai kompleksitas sebagai output. Tujuan dirancangnya sistem ini adalah memudahkan pengguna dalam melakukan perhitungan metrik skala dan kompleksitas arsitektur bisnis.

\section{HASIL DAN PEMBAHASAN}

\section{Use Case}

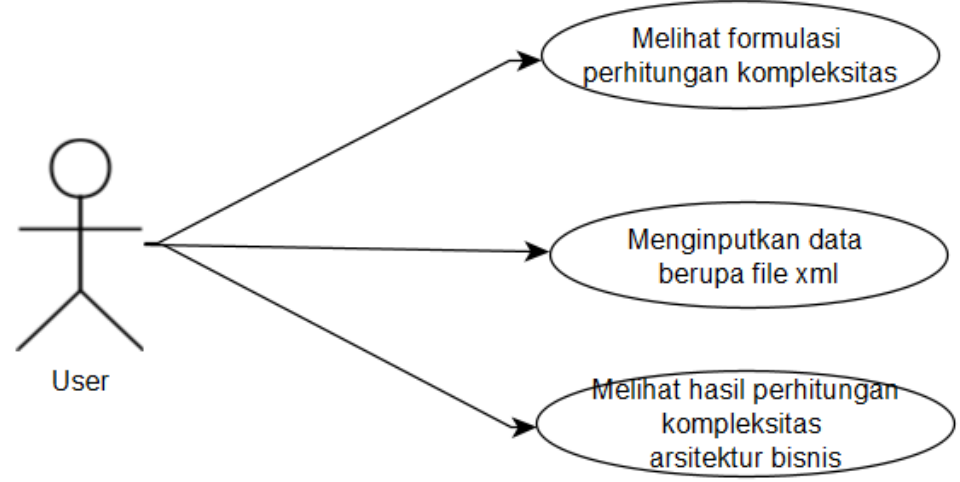

Gambar 7. Use Case Sistem Perhitungan Kompleksitas Arsitektur Bisnis

Dalam gambar 7 ini menjelaskan tentang kebutuhan fungsional perancangan Software yang kami buat. Dalam gambar 7 tersebut menggambarkan apa saja yang dapat dilakukan oleh user atau pengguna.

\section{Hasil Perhitungan Skala Kompleksitas}

Berdasar hasil konversi data pada tabel ke 2 kemudian dilakukan perhitungan dengan menggunakan rumus (1) untuk menghasilkan kompleksitas masing-masing komponen struktur organisasi. Hasil perhitungan yang dilakukan dapat dilihat pada Tabel 4. 
Tabel 3.Perhitungan Kompleksitas Komponen Struktur Organisasi

\begin{tabular}{|c|c|c|c|c|c|c|c|}
\hline No & Komponen & Job description & $\frac{\text { SOP }}{A \times N}$ & $B \times e$ & $\begin{array}{l}\text { Avrg } \\
\text { Scale }\end{array}$ & $\boldsymbol{C} \times \boldsymbol{E}$ & Scale \\
\hline 1 & $\begin{array}{l}\text { Kepala } \\
\text { Sekolah }\end{array}$ & $\begin{array}{l}\text { Bertanggung jawab atas seluruh } \\
\text { pengelolaan, pembinaan, dan } \\
\text { pengembangan OSIS }\end{array}$ & 1,631 & 2,574 & 4,205 & 2,028 & 6,233 \\
\hline 2 & $\begin{array}{l}\text { Wakil Kepala } \\
\text { Sekolah }\end{array}$ & $\begin{array}{l}\text { Membantu kepala sekolah dengan } \\
\text { memberikan nasihat dan mengadakan } \\
\text { evaluasi pelaksanaan tugas OSIS }\end{array}$ & 1,864 & 3,432 & 5,296 & 1,352 & 6,648 \\
\hline & \multirow{4}{*}{ Pembina } & $\begin{array}{l}\text { Mengesahkan dan melantik pengurus } \\
\text { OSIS dengan Surat Keputusan } \\
\text { Kepala Sekolah }\end{array}$ & 1,864 & 3,003 & \multirow{4}{*}{$\begin{array}{l}4,8577 \\
5\end{array}$} & \multirow{4}{*}{7,098} & \multirow{4}{*}{$\begin{array}{l}11,9557 \\
5\end{array}$} \\
\hline 3 & & $\begin{array}{l}\text { Mengarahkan penyusunan Anggaran } \\
\text { Rumah Tangga dan Program Kerja } \\
\text { OSIS }\end{array}$ & 2,097 & 3,861 & & & \\
\hline & & $\begin{array}{l}\text { Mengawasi kinerja pengurus OSIS } \\
\text { dan bertanggung jawab ke kepala } \\
\text { sekolah }\end{array}$ & 1,631 & 3,003 & & & \\
\hline & & Mengevaluasi kinerja OSIS & 1,398 & 2,574 & & & \\
\hline \multirow{3}{*}{4} & \multirow{3}{*}{ Ketua } & $\begin{array}{l}\text { Menetapkan kebijaksanaan dengan } \\
\text { bermusyawarah atau direncanakan } \\
\text { bersama pengurus lain }\end{array}$ & 1,864 & 3,861 & \multirow{3}{*}{5,439} & \multirow{3}{*}{7,774} & \multirow{3}{*}{13,213} \\
\hline & & $\begin{array}{l}\text { Menetapkan kebijaksanaan dengan } \\
\text { persetujuan pembina }\end{array}$ & 1,864 & 3,432 & & & \\
\hline & & $\begin{array}{l}\text { Mengevaluasi kegiatan seluruh } \\
\text { departemen }\end{array}$ & 1,864 & 3,432 & & & \\
\hline \multirow{2}{*}{5} & \multirow{2}{*}{ Wakil Ketua } & $\begin{array}{l}\text { Membantu ketua dalam setiap } \\
\text { musyawarah }\end{array}$ & 1,864 & 3,861 & \multirow{2}{*}{5,8415} & \multirow{2}{*}{2,028} & \multirow{2}{*}{7,8695} \\
\hline & & $\begin{array}{l}\text { Mengkoordinasikan departemen- } \\
\text { departemen }\end{array}$ & 2,097 & 3,861 & & & \\
\hline \multirow{2}{*}{5} & \multirow{2}{*}{ Sekretaris } & $\begin{array}{l}\text { Mendampingi ketua dalam setiap } \\
\text { rapat }\end{array}$ & 1,398 & 2,574 & \multirow{2}{*}{5,1795} & \multirow{2}{*}{1,352} & \multirow{2}{*}{6,5315} \\
\hline & & $\begin{array}{l}\text { Membuat laporan atau proposal dan } \\
\text { surat menyurat }\end{array}$ & 2,097 & 4,29 & & & \\
\hline \multirow[t]{2}{*}{7} & \multirow[t]{2}{*}{ Bendahara } & $\begin{array}{l}\text { Membantu sekretaris dalam } \\
\text { mengerjakan proposal atau laporan } \\
\text { bagian keuangan }\end{array}$ & 1,864 & 3,432 & \multirow[t]{2}{*}{6,1725} & \multirow[t]{2}{*}{3,718} & \multirow[t]{2}{*}{$\mathbf{9 , 8 9 0 5}$} \\
\hline & & $\begin{array}{ll}\text { Membuat } & \text { laporan } \\
\text { pertanggungjawaban } & \end{array}$ & 2,33 & 4,719 & & & \\
\hline \multirow{2}{*}{$\beta$} & \multirow{2}{*}{ Departemen 1} & $\begin{array}{l}\text { Mengadakan kegiatan lomba yang } \\
\text { bernuansa keagamaan }\end{array}$ & 3,961 & 7,293 & \multirow{2}{*}{9,599} & \multirow{2}{*}{3,042} & \multirow{2}{*}{12,641} \\
\hline & & $\begin{array}{l}\text { Memperingati hari-hari besar } \\
\text { keagamaan }\end{array}$ & 2,796 & 5,148 & & & \\
\hline 9 & Departemen 2 & Melaksanakan kegiatan bela negara & 3,029 & 6,006 & 9,035 & 2,366 & 11,401 \\
\hline \multirow{3}{*}{10} & \multirow{3}{*}{ Departemen 3} & $\begin{array}{l}\text { Mengadakan studi banding dan } \\
\text { kunjungan (studi wisata) }\end{array}$ & 2,796 & 5,148 & \multirow{3}{*}{8,892} & \multirow{3}{*}{3,718} & \\
\hline & & $\begin{array}{l}\text { Menyelenggarakan } \\
\text { lomba seni }\end{array}$ & 3,262 & 6,435 & & & 12,61 \\
\hline & & Mengadakan pameran karya & 3,029 & 6,006 & & & \\
\hline
\end{tabular}

Dari Tabel ke 4 dapat dilihat bahwa angka kompleksitas tertinggi dimiliki oleh ketua dengan angka kompleksitas 13,213. Sedangkan kompleksitas terendah adalah kepala sekolah dengan angka kompleksitas 6,233. 


\section{Analisis Grafik Kompleksitas}

Kompleksitas struktur organisasi kemudian di gambarkan ke dalam grafik untuk mengetahui pengaruh skala kompleksitas terhadap struktur organisasi menggunakan metode regresi linier.

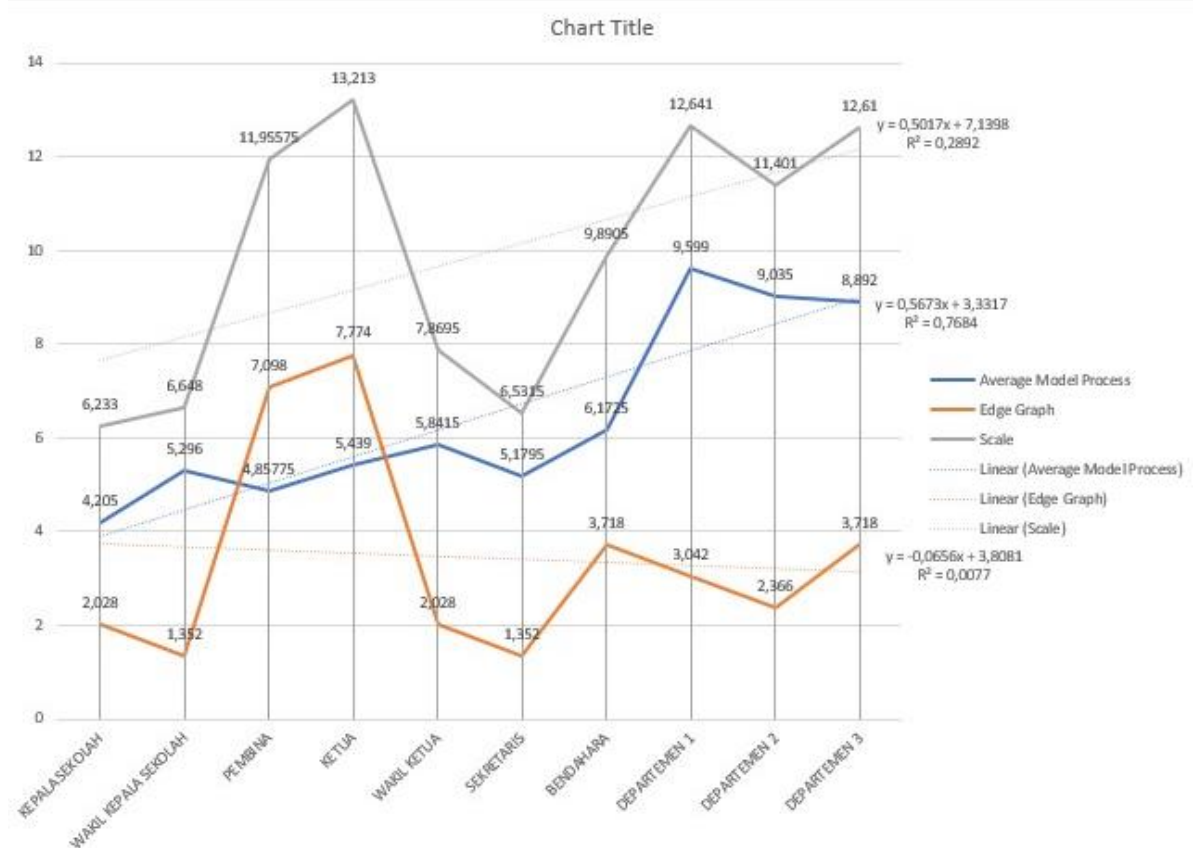

Gambar 8. Grafik Kompleksitas Struktur Organisasi

Dari grafik pada gambar 8 dapat diketahui besaran koefisiensi regresi, intersep dan koefisien determinasi dari scale, edge graph, dan rata-rata dari node dan edge dari model proses yang dapat dilihat pada Table 5 .

Tabel 4. Hasil Regresi Linier dari Kompleksitas Organisasi

\begin{tabular}{|lllc|}
\hline Metrik & Koefisien Regresi & Intersep & Koefisien Determinasi \\
\hline Scale & 0,5017 & 7,1398 & 0,2892 \\
\hline Average Model Process & 0,5673 & 3,3317 & 0,7684 \\
\hline Edge Graph & $-0,0656$ & 3,8081 & 0,0077 \\
\hline
\end{tabular}

Dari ketiga koefisien regresi pada table ke 5 dua diantaranya menunjukkan hasil positif yaitu koefisien scale sebesar 0,5017 dan koefisien dari average model process sebesar 0,5673 . Hasil positif dari koefisien regresi ini berpengaruh lurus pada keefektivan organisasi yang mana berarti bahwa organisasi tersebut akan semakin efektif apabila ada penambahan komponen organisasi yang berpengaruh pula pada tingkat kompleksitasnya. Namun pada poin ini dilihat kembali koefisien regresi dari edge graph yang bernilai negatif. Apabila nilai positif dari koefisien regresi dapat meningkatkan keefektifan organisasi, maka sebaliknya apabila koefisien regresi bernilai negatif maka akan berdampak negatif pada organisasi di mana akan menurunkan keefektifan organisasi. Sehingga pada penambahan komponen pada organisasi akan berdampak pada penurunan tingkat keefektifan organisasi. Meskipun terdapat nilai negatif pada koefisien regresi dapat diketahui bahwa organisasi dapat tumbuh dan berkembang sebab koefisien positif masih memiliki jumlah lebih besar daripada koefisien negatif. Koefisien regresi bernilai positif meningkatkan keefektivan organisasi yang berarti organisasi tersebut dapat tumbuh.

Meninjau koefisien determinasi yang mempengaruhi seberapa besar variable yang maksudkan mempengaruhi keefektivan sebuah organisasi didapat data bahwa pengaruh 
paling tinggi didapat dari average model proses dimana terdapat 0,7684 atau sekitar $76 \%$ variable ini mempengaruhi kefektivan organisasi. Sedangkan variabel scale memiliki peran sekitar 28\% untuk keefektivan organisasi. Dan edge graph memiliki pengaruh paling kecil yaitu hanya sebesar $0,7 \%$.

\section{KESIMPULAN}

Berdasarkan hasil penelitian Analisis dan Perancangan Software Pengukuran Metrik Skala dan Kompleksitas Arsitektur Bisnis dapat diambil kesimpulan bahwa kompleksitas sebuah arsitektur bisnis dapat dilihat melalui struktur organisasinya. Dimulai dari komponen organisasi, job description, Standar Operasional Prosedur (SOP), dan hubungan antar komponen organisasi (stakeholder). Dari hasil perhitungan dan analisis grafik pada gambar 4 diperoleh hasil bahwa pengaruh keefektivan organisasi terbesar terletak pada average model process yaitu sekitar $76 \%$ dan scale sekitar $28 \%$. Keduanya memiliki koefisien regresi positif di mana menunjukkan bahwa organisasi tersebut efektif dan tumbuh. Sedangkan variable edge graph memiliki pengaruh $0,7 \%$ terhadap keefektivan organisasi dan memiliki koefisien negative yang berarti dapat menurunkan kefektivan organisasi. Namun karena prosentase pengaruh yang cukup kecil, organisasi masih dapat tetap tumbuh karena keefektivan organisasi tidak berpengaruh cukup signifikan. Penelitian dalam paper kali ini masih sebatas pada rancangan sistem dan perhitungan sederhana. Penulis berharap agar penelitian ini diimplementasikan pada sistem yang sesungguhnya. Penulis menyadari masih banyak terdapat kekurangan sehingga diperlukan penyempurnaan teori maupun formula untuk penelitian selanjutnya.

\section{REFERENSI}

[1] S. Najah, M. Ainul Yaqin, L. S. Angreani, and A. C. Fauzan, "Mengukur Akurasi Query Pada Interface Repository Menggunakan User Interface (UI) Discovery Berbasis Software as a Service (SAAS)," BRILIANT J. Ris. dan Konseptual, vol. 4, no. 1, pp. 206-214, 2019, doi: http://dx.doi.org/10.28926/briliant .v3i4.312.

[2] M. A. Yaqin, R. Sarno, and A. C. Fauzan, "Scalability measurement of business process model using business processes similarity and complexity," in International Conference on Electrical Engineering, Computer Science and Informatics (EECSI), 2017, vol. 4, no. September, pp. 306-312, doi: 10.11591/eecsi.4.1033.

[3] S. Kasus, P. Kemenkes, P. Raya, F. Berthanio, and B. L. Sinaga, "Perancangan arsitektur bisnis perguruan tinggi dengan togaf (studi kasus : politekkes kemenkes palangka raya),” pp. 978-979, 1972.

[4] S. Kotusev, "The Process View of Enterprise Architecture Practice," no. October, 2019.

[5] Y. M. Maulana et al., "Perencanaan Arsitektur Enterprise Untuk Pada Bagian Administrasi Akademik Stikom Surabaya Enterprise Architecture Planning To Enhance Service Management Quality In Academic Administration," 2015.

[6] S. Purworaharjo, "Study Komparatif Enterprise Architecture pada Tiga Negara Berdasarkan Index EGov pada Waseda International E-Gov Rangkings," vol. 10, no. 2, pp. 1570-1577, 2018.

[7] S. Ramadhani et al., "Pemodelan Arsitektur Enterprise Menggunakan Enterprisearchitecture Planning Jambi ( Studi Kasus : KANWIL Kementerian Agama Provinsi Jambi ),” vol. 1, no. 2, pp. 191-207, 2016.

[8] N. Rizky and A. F. Firmansyah, "PERENCANAAN ARSITEKTUR ENTERPRISE MENGGUNAKAN TOGAF ADM VERSI 9 ( Studi Kasus : Bimbel Salemba Group ),” vol. 10, no. 1, pp. 11-20, 2017.

[9] S. A. Rumapea and K. Surendro, "PERENCANAAN ARSITEKTUR ENTERPRISE PENYELENGARAAN PELAYANAN TERPADU SATU PINTU ( USULAN : DINAS PERIJINAN )," vol. 2007, no. 24, 2007.

[10] H. Saputra and A. L. Belakang, "Sistem Pendukung Keputusan Penerimaan Beasiswa PPA Dan BBM Pada Perguruan Tinggi Swasta Provinsi Sumbar, Riau , Jambi Dan Kepri Di Kopertis Wilayah X Padang Menggunakan Metode AHP ( Analytical Hierarchy Process ) Process )," vol. 02, no. 03, 2016.

[11] E. Suseno, "Pemodelan Arsitektur Enterprise Perguruan Tinggi Dengan Metode Togaf ( Studi Kasus Universitas Nahdlatul Ulama Cirebon ),”vol. 1, pp. 1-9. 